\title{
ANALYSIS OF PUBLIC DEBT AT SUBNATIONAL GOVERNMENT LEVELS: EVIDENCE FROM CANTONS IN THE FEDERATION OF BOSNIA AND HERZEGOVINA
}

Jasmin Halebić, Amina Moćević

\section{Abstract}

Total public debt of ten cantons in the Federation of Bosnia and Herzegovina (FBiH), one of the two entities in $\mathrm{BiH}$, have substantially increased in recent years. Since it is relatively small in nominal terms, this galloping trend have not attracted enough attention of decision makers. If these developments continue in the future, the public debt at cantonal level in FBiH might create serious fiscal problems and become one of central issues for policy makers. This has motivated our investigation of determinants that caused the increase in public debt over the period 2012-2018.

We apply a panel regression analysis and investigate how budget deficit, trade balance, unemployment rate, size of population and institutional changes affect public debt. We find that public debt is positively associated with budget deficit but negatively associated with trade balance, the size of population and institutional changes. These findings motivated policy recommendations presented in the paper.

Key words: public debt, Federation of Bosnia and Herzegovina, subnational governments

JEL classification: $H 68, H 74$

\section{INTRODUCTION}

Public debt is an important indicator of sound and sustainable public finance and fiscal policy in each country. When public debt increases it is inevitable to expect negative effects in the economy over time, including decrease in investments and a need to introduce austerity measures, which by definition can have regressive consequences. Accumulation of current public debt in many emerging markets' and developing economies might turn into financial crisis with immense negative consequences (Kose et al. 2020).

Public debt and its effects on economic outcomes are on-going topic in the literature, but still the subject remains unexplored, especially for the country in our focus. Generally, researchers investigate the effects of public debt at country level using various aggregate variables from the System of national accounts (Sinha, Arora, and Bansal 2011; Bittencourt 2015; Omrane

Jasmin Halebić, PhD (corresponding author)

Associate professor

Faculty of Economics

University of Zenica

E-mail: jasmin.halebic@ef.unze.ba

Address: Ekonomski fakultet,

Fakultetska br. 3, 72000 Zenica

Amina Moćević, PhD student

Ministry of Finance

Canton Sarajevo

E-mail:amina.mocevic@mf.ks.gov.ba 
Belguith and Omrane 2017). Special research attention in the related literature has been given to the European Union and the Eurozone countries, as one of the convergence criteria for joining the Eurozone is appropriate control of public debt (Franks et al. 2018). Those countries that managed to keep their public debt below the Maastricht criteria level $(60 \%$ of GDP) have experienced higher economic growth rates, which applies to both, the Euro and non-Euro EU member countries (Bökemeier and Clemens 2016). It is also well recognized that excessive debt levels in Eurozone member countries create substantial risk to the EMU itself. In some cases, public sector debt is also linked with the current account deficit, which creates burden to national budgets when it reaches high levels (Tokarski 2019).

As a matter of fact, public finance analysis at subnational level is less accentuated in the literature than that of national level. This might be due to the fact that national statistical agencies rarely publish subnational public finance data. Therefore, a lack of research and consequently poor policy recommendations in this subfield is a feature of this literature. But, importance of investigation of the public debt at subnational levels is emphasized by the fact that most questions of practical nature for ordinary citizens and SMEs are regulated very often at subnational levels. Additionally, if public debt at subnational level is considered sustainable in eyes of investors then interest payments for the debt financed investments will be more affordable. Hence, sound public finance and manageable public debt at subnational levels are of crucial interest for citizens and businesses.

It is stipulated in relevant laws in $\mathrm{FBiH}$ that local governments, within their competence and jurisdiction, bear the sole responsibility for their own public debt management. Higher levels of government do not take any responsibility whatsoever related to public debt management of local governments. Nodeficit-carryover principle is also one of fiscal rules in $\mathrm{FBiH}$ that contributes to debt accountability of lowertier governments at all levels. However, cantons (there are ten cantons in $\mathrm{FBiH}^{1}$ ) do not have sufficient financial power since only few laws that generate public revenues are in cantonal jurisdiction. ${ }^{2}$ About $5 \%$ of budget revenues is generated by laws in cantonal jurisdiction and cantons cannot rely on it in their debt management strategies. In some other countries, such as Switzerland, cantons are provided with stronger financial basis having tax autonomy in personal, corporate and property taxes (Kirchgässner 2013). Hence, the question of successful debt management at cantonal levels in $\mathrm{FBiH}$ becomes even more important.

Bosnia and Herzegovina is a decentralized country in terms of financial competences. For instance, Value Added Tax (VAT) and other forms of indirect taxation are in jurisdiction of the state level, while income tax, profit tax, property tax and other forms of direct taxation are at the lower levels of government. Since $\mathrm{BiH}$ is composed of two entities, namely, $\mathrm{FBiH}$ and the Republika Srpska entity, plus the District Brcko of $\mathrm{BiH}$, public debt is administered at numerous levels. Cantons are intermediate level of government located between the $\mathrm{FBiH}$ level and the municipalities. Furthermore, $\mathrm{FBiH}$ is organized as a fiscally decentralised entity (federal level, cantons, cities and municipalities). Subnational level in this paper refers to ten cantons in $\mathrm{FBiH}$.

The issue of sustainability of public debt is not considered priority in the current institutional environment of $\mathrm{FBiH}$ since the relevant laws for budget planning and public borrowing impose strong fiscal rules starting from the borrowing level restrictions to the conditioning the positive primary budget balance and total budget balance (where revenues and receipts are equal to expenditures and outlays). Relevant laws in $\mathrm{FBiH}$ also prioritize the debt repayment over other payments from budget, so the risk of default on public debt repayment nearly does not exist.

Sustainability of public debt correlates with fundamental macroeconomic indicators (Albu and Pelinescu 2000) and also depends on the primary fiscal balance. According to the Law on budgets in $\mathrm{FBiH}$, the primary fiscal balance ought to be positive or neutral (i.e. equal to zero) and this fiscal rule enormously contributes to the public debt sustainability. ${ }^{3}$ Moreover, fiscal rules are often designed without possibility for monetization of public debt by monetary policy, which applies to $\mathrm{BiH}$. In the absence of active monetary policy in $\mathrm{BiH}$, it is important to rely on strong fiscal rules to prevent the necessity of monetization of the public debt. Regardless, the context of public debt as a part of fiscal policy will be important to study in the near future (when more data become available for $\mathrm{FBiH}$ ) including all elements of sustainability that can be found in the relevant literature. ${ }^{4}$

The main purpose of this paper is to address public debt at subnational levels in $\mathrm{FBiH}$ and examine factors which affect the size and variability of public debt. We investigate the public debt of ten cantons in $\mathrm{FBiH}$, while the bulk of the public debt is at FBiH entity level and less of it at municipality level. Subnational governmental levels in $\mathrm{FBiH}$ have begun to increase their public debt as a result of decreasing public revenues during the crisis period (Basaric, Brankovic, and Lazovic-Pita 2018). Similar debt structures are observed in other countries (Kirchgässner 2013). However, we hypothesize that public debt of 
subnational levels, i.e. cantons, is a consequence of different economic determinants. Some authors who are mainly coming from the political sciences (e.g. Ellis and Schansberg 1999; Feld and Kirchgässner 2001), also include non-economic factors in their analyses, stressing a way of budgeting and other aspects of political life that change debt accumulation in times of fragmented/unstable governments. From that politico-economic perspective, a group of empirical models appeared in the literature (e.g. Pettersson-Lidbom 2001; Benito and Bastida 2004; Ashworth, Geys, and Heydels 2005). However, we restrained from that line of reasoning and limited the scope of the paper to standard economics analytical framework.

The paper is structured as follows. After this introductory section in the next one we present literature review and introduce our econometric model. The third section describes methodology and the data used in the empirical investigation. The econometric analysis and the obtained results are presented in the fourth section. In concluding section, we summarize the main findings and propose some recommendations, both of practical and of theoretical nature.

\section{LITERATURE REVIEW}

The existing literature explains several ways in which public debt affects economic activity. We consider the debt as the accumulation of previous public deficits (Stiglitz and Rosengard 2015). An increasing public debt can have the following consequences: transfer of the burden of current expenditures to future generations; reduction of investment and capital accumulation since economic subjects tend to substitute debt for capital; lowering of living standards in the future through unavoidable foreign borrowing; negative savings of the state which cannot be reduced by private savings, etc. It also might affect consumption or limit the size and effectiveness of expansionary fiscal policy measures during economic downturns and dampen long-term growth by weighing on productivity-enhancing private investment (Kose et al. 2020).

Obviously, the debt will not get out of control at any government level if incumbent government increases revenues and/or cut expenditures (Mahdavi 2014). From a long-run perspective, cutting expenditures in subnational governments in order to achieve sustainable public debt levels can also cause some negative consequences, if it is done through reduction of investments in local infrastructure programs or financing services and communal public utilities (Bröthaler, Getzner, and Haber 2015). Problems with unsustainable fiscal policies at (sub)national levels could be further exacerbated with economic crises bursting or volatility in foreign exchange rates if the debt were issued in foreign currency.

Borrowing as a way of financing local government capital projects is also emphasized in the literature (Kitchen, McMillan, and Shah 2019). Higher levels of government often exert control over local governments' access to capital markets because the former reluctantly accepts any responsibility holding the latter completely accountable for sustainability of its own fiscal policies. Local debt burden is a particularly relevant indicator of fiscal sustainability of a government (Gorina 2013) and it is usually measured as a ratio of local direct debt or total local long-term debt divided by population or personal income or some form of asset revaluation.

Skidelsky (2018) points out that the UK Treasury policy in period 2010-2016 aimed to implementing government austerity measures were motivated to reducing deficits and consequently reducing public debt. The author explains that this policy was unsuccessful because at the same time the austerity measures caused shrinking of the economy (measured by real GDP growth), which resulted in higher non-expected debt levels. Contrary to this policy, Bittencourt (2015) reports evidence that economic growth is able to significantly reduce the debt ratios.

The trade deficit has a significant impact on the budget deficit. In the case of trade deficit, tax revenues are higher and the budget deficit tends to be smaller in the short run, thus often motivating the government to lean less on debt issuance for financing of its programs. Importantly, Santini (2020) argues that there is no difference between increasing tax revenues based on foreign trade deficits and public debt.

Public debt of Austrian municipalities, for example, increased in years when Austria joined the EU and, consequently, the country had to reduce public deficits substantially (Bröthaler et al. 2015). The authors also observed the primary surplus of municipality as one of the central indicators for the sustainability of budgetary policies, and besides debt, they focused on the unemployment rate, GDP of the municipality and population as explanatory variables in their analysis. One of conclusions was that larger municipalities, compared to smaller ones, were able to respond in different ways to increasing local debt, such as: easier access to provincial or national funds and stronger fiscal strength with respect to higher fiscal revenues of their own, thanks to attractive location for businesses.

Research on public debt within a country is recommended in literature (e.g. Alesina and Passalacqua 2016) since different public policies may exist in localities within one country. This kind of studies 
should focus on determinants of public debt in a current institutional setting. Therefore, we focus on literature including primarily Benito and Bastida (2004); Ashworth, Geys, and Heydels (2005); Veiga and Veiga (2014); Bogumil et al. (2014); Balaguer-Coll, Prior, and Tortosa-Austina (2015); Ehalaiye, Botica-Radmayne, and Laswad (2017); Bellot, Sellva, and Menendez (2017); Omrane Belguith and Omrane (2017); etc. This literature review revealed a whole list of public debt determinants at subnational level. From the literature review we could not identify a unique model specification for our investigation and model. These authors also focus on financial, social and political variables, which make such investigation even more demanding. However, following the investigated literature, $\mathrm{BiH}$ specifics and data availability, we built an empirical model which includes economic variables: budget deficit, trade balance and unemployment rate as important economic determinants of public debt. Moreover, our model controls for specific institutional changes and the size of population as relevant determinants for investigation of public debt at cantonal levels in $\mathrm{FBiH}$.

\section{RESEARCH METHOD AND DATA}

In comparison with other countries, local governments in $\mathrm{FBiH}$ have accumulated lower debt than higher levels of government. ${ }^{5}$ Figure 1 presents public debt at different administrative levels in $\mathrm{FBiH}$ for the period 2012-2018.

In the examined period, subnational public debt at cantonal level exceeded $20 \%$ of the public debt in $\mathrm{FBiH}$, confirming that the major part of the public debt is located at the entity level. With the growth of debt at the cantonal level in year 2013, the debt at the entity level of $\mathrm{FBiH}$ decreases in almost the same proportion. Thus, such behaviour of public debt indicators gives rise to the importance of our research focus.

\subsection{Data Collection}

In this paper we focus on 10 cantons in $\mathrm{FBiH}$ over the period 2012-2018. The data at cantonal government debt levels were taken from the Federal Ministry of Finance, which is in charge of the debt data collection at all levels of government in $\mathrm{FBiH}$. The data on cantonal deficits are taken from the Centre for Advocacy for Civic Interests, ${ }^{6}$ which maintains a public finance database at all levels in $\mathrm{BiH}^{7}$ The data on trade balance, unemployment and population were taken from the Federal Institute for Statistics.
Figure 1. Public debt in Federation of $\mathrm{BiH}(\%)$

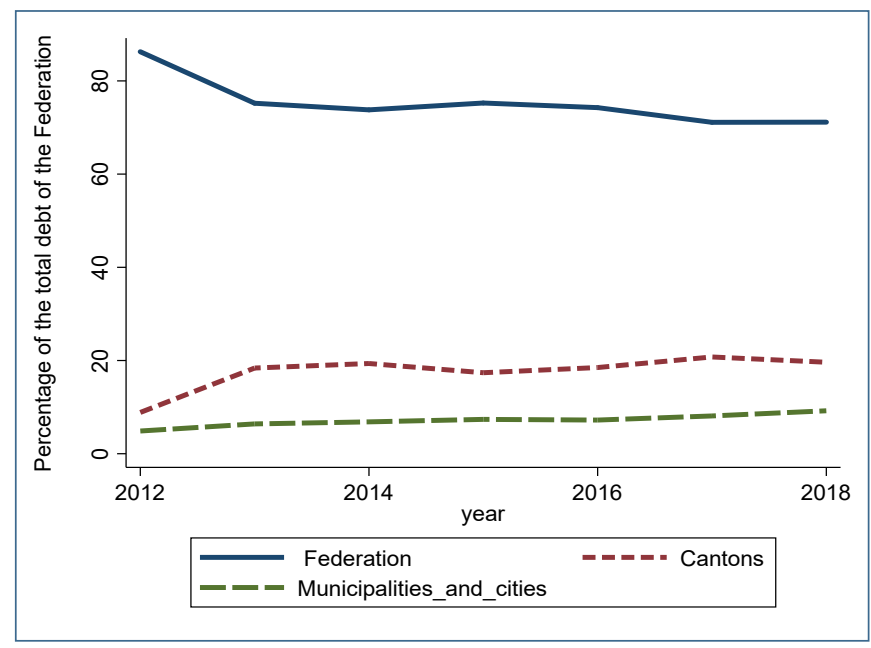

Source: Ministry of Finance and Treasury of BiH 2012-2018

\subsection{Variables}

In order to measure the level of indebtedness in 10 cantons of $\mathrm{FBiH}$ and to analyse how the relevant variables influence the levels of this debt we specify a model in which dependent variable is public debt per capita at cantonal level. Public debt appears in different forms as the dependent variable and a measure of fiscal sustainability in the existing literature (e.g. Benito and Bastida 2004; Gorina 2013; Mahdavi 2014; Veiga and Veiga 2014; Brothaler et al. 2015; Alesina and Passalacqua 2016; Omrane Belguith and Omrane 2017; etc.).

However, due to severe data limitations at the cantonal level in $\mathrm{FBiH}$, we were unable to build the debtto- or primary surplus-to-nominal GDP ratio variables, often identified in the previous studies. Consequently, we rely on a proxy variable formed as a summation of external debt loans, domestic debt loans, guarantees and bonds as presented in Figure 2, and used in some research (e.g. Balaguer-Coll, Prior, and Tortosa-Ausina 2015). Summation of all these types of debt in per capita terms represents the dependent variable of the model.

Following the existing literature, we include budget deficit as the independent variable in the model. The relationship between spending and taxes do not provide a complete picture of government policy. Thus, deficit and deficit policy have a major impact on the level of borrowing and, consequently, on public debt. In our model the budget deficit (i.e. total revenues minus total expenditures) is lagged for one year. Namely, in accordance with the law, the budget deficit in the previous year might create an obligation for borrowing in the next year, which motivated this choice 
Figure 2. Structure of total debt at the cantonal level 2012-2018

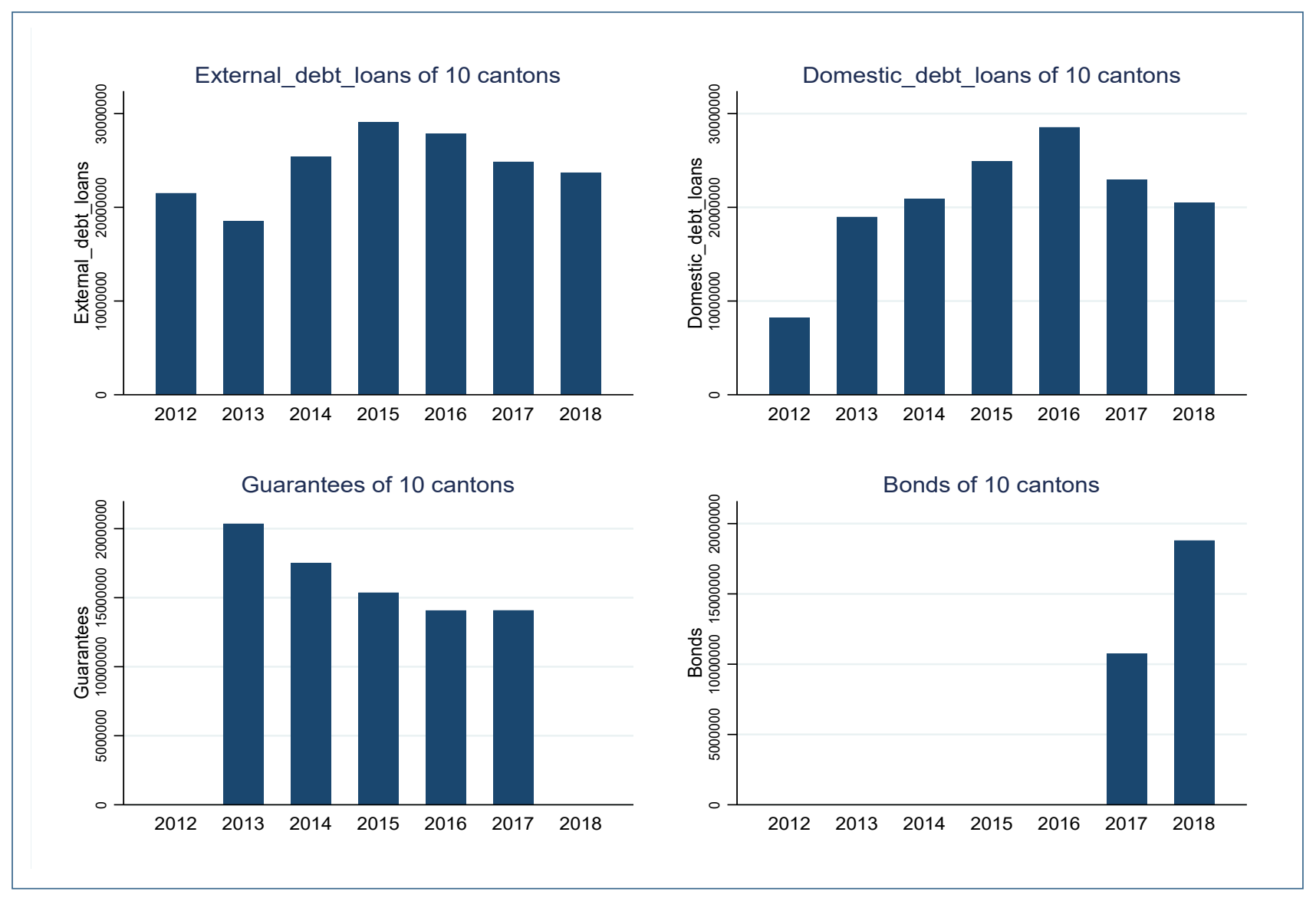

Source: Federal Ministry of Finance in $\mathrm{BiH}$ 2012-2018.

VAT is the most important source of public revenues in all cantons in $\mathrm{FBiH}$. It makes the highest percentage share of the total tax revenues in all cantons. Generally, public revenues from indirect taxes are not always an outcome of increased economic activity, but can also be caused by higher imports activities, i.e. by increasing trade deficit. Therefore, the larger the trade deficit, the lower the cantons' public debt level. Accordingly, following the existing literature (e.g. Santini 2020) we assume that one of the determinants of public debt in the cantons is their trade balance, which is the second independent variable in the model. There are theoretical implications of the impact of trade balance on public debt on country level (Santini 2020), but the issue is still empirically under investigation.

The size of population is one of the criteria for the distribution of public revenues from indirect taxes in $\mathrm{FBiH}$. As an illustration, a higher population density in Portuguese local governments' was found to be associated with lower indebtedness (Veiga and Veiga 2014), although the effect of density is not always found to be relevant (Balaguer-Coll, Prior, and Tortosa-Ausina
2015). A significant positive relationship between the size of local population and per capita debt service was also confirmed in the literature (e.g. Medve-Balint and Bohle 2016). Population size has statistically significant positive effect on debt (Ashworth, Geys, and Heyndels 2005) since debt arises from additional demand for public expenditures in the long run in countries with larger population. Simply, this is a variable worth controlling in our model.

Strong economic growth should reduce total unemployment, which leads to additional public revenues. According to the Okun's law, there is a negative relationship between output gap and unemployment (Krugman and Wells 2018). An increase in output and decrease in unemployment can lead to higher tax revenues that, in turn, can lead to a smaller public debt. Consequently, our next independent variable is cantonal unemployment rate as proxy for the output level performance (following Okun's law arguments). Unemployment is identified as a variable used in similar models (e.g. Wassmer and Fisher 2011; Veiga and Veiga 2014; Bogumil et al. 2014; Bröthaler et al. 2015; Medve-Bálint and Bohle 2016). 
In the end, it is important to mention that the Law on Public Revenues Determination (LPRD) has been changed in 2015, which affected the public revenue distribution at subnational levels in $\mathrm{FBiH}$. Other aspects of the relationship established between subnational and national levels (i.e. cantons and $\mathrm{FBiH}$ and the state) have been pretty much unchanged during the period. Having in mind that this structural brake could systematically affect public debt at cantonal level, we control for this institutional change ${ }^{8}$ by introducing a dummy variable (LAW: 0 for period prior to 2015 and 1 for period afterwards). Some authors took similar approach by analysing changes in local government institutional conditions, for example, in pre- and post-crisis periods (Bisogno et al. 2019).

While some authors argue that political variables are not relevant to debt financing (Ellis and Schansberg 1999), others introduce political variables to measure the effects of electoral cycles on fiscal outcomes (Kachelein, Lami, and Imami 2010; Lami, Kachelein, and Imami 2014). The authors scrutinized carefully the effect of electoral cycles on fiscal outcomes and made a case in favour of the influence of political cycles on number of economic indicators. Thus, elections were identified as a potential determining factor of public debt with assumption that public debt could increase in the election years due to the fiscal illusion of voters. However, electoral cycles are very specific in $\mathrm{FBiH}$ because they are being organized every second year as general and local elections. Besides this, our research is focused on economic determinants, therefore elections as a variable are out of the scope of this research, but worth exploring in the future. All in all, we complete our discussion with Table 1, which summarizes variables used in the model, including expected sign to be estimated.

Eventually, it is inevitable to mention the issue of causality between institutions and fiscal outcomes, which has been recommended to be considered in similar research (Alesina and Passalacqua 2016). Unfortunately, the data availability at the cantonal

Table 1. Independent variables and expected relationships

\begin{tabular}{|ll|}
\hline $\begin{array}{l}\text { Independent } \\
\text { variable }\end{array}$ & $\begin{array}{l}\text { Expected } \\
\text { relationships }\end{array}$ \\
\hline Budget deficit rise & Positive \\
Trade balance rise & Negative \\
Population rise & Positive \\
Unemployment rate decline & Positive \\
Law amendments introduced & Positive \\
\hline
\end{tabular}

Source: Authors' creation level, including the sample size, did not give us more space for such kind of empirical testing, and this remains to be addressed in the future research when more data will be available.

\subsection{Model specification}

The main variables of our model specification are introduced in the previous section and linked to the existing literature. Thus, the model specification reflects the existing literature by using the following independent variables, starting with budget deficit/ surplus 9 (e.g. Benito and Bastida 2004; Balaguer-Coll, Prior, and Tortosa-Ausina 2015) and the size of population (e.g. Benito and Bastida 2004; Bogumil et al. 2014; Bittencourt 2015). Next, unemployment is identified as a relevant variable in similar models (Wassmer and Fisher 2011; Veiga and Veiga 2014; Bogumil et al. 2014; Bröthaler et al. 2015; Medve-Bálint and Bohle 2016) but we use unemployment rate to take into account the size of cantons (e.g. Koomin and Seunghoo 2018) including change in fiscal institutional environment which is specific to $\mathrm{FBiH}$ and the period under observation (similar research is by Koomin and Seunghoo 2018). The literature (e.g. Omrane Belguith and Omrane 2017) often uses the openness variable (exports + imports as a share of GDP) as an independent variable that explains public debt. Recall, there are no GDP statistics for 10 cantons in $\mathrm{FBiH}$, and we use the trade balance (exports-imports of goods) as the best available proxy.

Finally, we estimate the model based on panel data from 10 cantons in $\mathrm{FBiH}$ and the period 2012-2018 with the following empirical specification:

$$
\begin{gathered}
\ln D E B P c_{i t}=\beta_{0}+\beta_{1} D E F_{i t-1}+\beta_{2} T R D B_{i t}+ \\
\beta_{3} \ln P O P U L_{i t-1}+\beta_{4} U N E_{i t}+\beta_{5} L A W_{t}+\varepsilon_{i t}
\end{gathered}
$$

where $\ln D E B$ pcit denotes the dependent variable, i.e. total public debt per capita, $\beta_{0}$ refers to a constant term, $D E F_{i t-1}$ stands for budget deficit lagged for one year, $\beta_{1}$ denotes the regression coefficient which reflects the impact of deficit on the public debt. $\beta_{2}$ manifests the impact of trade balance $\left(T R D B_{i t}\right)$ on public debt, while $\beta_{3}$ shows the impact of the size of population $\left(\ln P O P U L_{i t-1}\right)$ lagged for one year in accordance with the LPRD. According to this law, the number of inhabitants is one of the criteria for the distribution of public revenues from indirect taxes in the cantons in $\mathrm{FBiH}$. Coefficient $\beta_{4}$ captures the impact of unemployment rate $\left(U N E_{i t}\right)$ while coefficient $\beta_{5}$ indicates the 
impact of law amendments, i.e. institutional change that occured in 2015. We use logarithmic transformation of some variables as they provide a better statistical diagnostic. ${ }^{10}$ Standard descriptive statistics and correlation matrix for variables used in the model are reported in Tables 2 and 3 below.

A look at the Pearson correlation matrix in Table 3 reveals that public debt at subnational government levels in $\mathrm{FBiH}$ is positively correlated with lagged budget deficit and with institutional change and negatively correlated with trade balance, lagged population and unemployment rate. We do not find worryingly high correlations between the variables which compose our model.

\subsection{Empirical results}

It is well known that the debt in one time period is affected by previous deficit and revenue distribution and therefore the variable that we use in our model have elements of simple dynamic model with lagged influences. The results of our estimation are presented in Table 4 (from panel Random effect and heteroskedasticity robust model).

The Hausman test was used to decide between static panel models with fixed or with random effects. Results of the Hausman test (Prob $>$ chi2 $=0.3808$ ) suggested the random effects (RE) model as a better fit. The advantage of RE estimation of the variables used in the model is that the differences through the observed units (i.e. cantons) have an impact on the dependent variable. The Wooldridge test was applied to test for auto-correlation, which proved to be correct $(p=0.3432)$, indicating that no autocorrelation in the model is detected. The likelihood-ratio test was utilized for testing heteroskedasticity in RE regression model. The results of $p$-value were significant pointing to the presence of heteroskedasticity. In order to correct the model for heteroskedasticity, we used an estimate with robust standard errors.

Table 2. Descriptive statistics

\begin{tabular}{|c|c|c|c|c|c|}
\hline Variable & Obs & Mean & Std.Dev & Min & Max \\
\hline $\begin{array}{l}\text { Ln DEBpc } \\
\text { Debt per capita in BAM, logarithm }\end{array}$ & 70 & 5.189 & 0.739 & 3.053 & 6.264 \\
\hline $\begin{array}{l}\text { DEF } \\
\text { Lagged budget deficit/budget surplus, } \\
\text { in millions BAM }\end{array}$ & 60 & -0.308 & 1.369 & -6.025 & 2.867 \\
\hline $\begin{array}{l}\text { TRDB } \\
\text { Export minus import, in millions BAM }\end{array}$ & 70 & -46.314 & 81.892 & -313.760 & 35.017 \\
\hline $\begin{array}{l}\text { Ln POPUL } \\
\text { Lagged number of inhabitants, logarithm }\end{array}$ & 60 & 11.962 & 0.983 & 10.058 & 13.120 \\
\hline $\begin{array}{l}\text { UNE } \\
\text { Unemployment rate, } \\
\text { In \% of labour force }\end{array}$ & 70 & 44.540 & 7.685 & 29.733 & 59.398 \\
\hline $\begin{array}{l}\text { LAW } \\
\text { Law on PRD ( } 0 \text { for years before the Law } \\
\text { was amended and } 1 \text { for years afterwards) }\end{array}$ & 70 & 0.428 & 0.498 & 0 & 1 \\
\hline
\end{tabular}

Source: Authors' estimates

Table 3. The correlation matrix

\begin{tabular}{|c|c|c|c|c|c|c|}
\hline Variable & Ln DEBpc & DEF & TRDB & Ln POPUL & UNE & LAW \\
\hline Ln DEBpc & 1.0000 & & & & & \\
\hline DEF & 0.1046 & 1.0000 & & & & \\
\hline TRDB & -0.4370 & 0.0968 & 1.0000 & & & \\
\hline Ln POPUL & -0.2348 & -0.1538 & -0.3477 & 1.0000 & & \\
\hline UNE & -0.5758 & -0.2516 & 0.5120 & 0.3341 & 1.0000 & \\
\hline LAW & 0.0814 & 0.4635 & -0.0402 & -0.0157 & -0.3239 & 1.0000 \\
\hline
\end{tabular}

Source: Authors' estimates 
Table 4. Regression results: Public debt at subnational-cantonal level in FBIH

\begin{tabular}{|c|c|c|c|c|c|}
\hline VARIABLES & $\begin{array}{c}\text { InDEBpcit } \\
\text { RE robust } \\
\text { (Est.1) }\end{array}$ & $\begin{array}{c}\text { InDEBpcit } \\
\text { RE robust } \\
\text { (Est.2) }\end{array}$ & $\begin{array}{c}\text { InDEBpcit } \\
\text { RE robust } \\
\text { (Est.3) }\end{array}$ & $\begin{array}{c}\text { InDEBpcit } \\
\text { RE robust } \\
\text { (Est.4) }\end{array}$ & $\begin{array}{c}\text { InDEBpcit } \\
\text { RE robust } \\
\text { (Est.5) }\end{array}$ \\
\hline \multirow[t]{2}{*}{ DEFit-1 } & 0.053 & 0.054 & 0.048 & $0.056^{*}$ & $0.071^{*}$ \\
\hline & $(0.034)$ & $(0.034)$ & $(0.031)$ & $(0.033)$ & $(0.042)$ \\
\hline \multirow[t]{2}{*}{ TRDBit } & & $-0.003^{* * *}$ & $-0.004^{* * *}$ & $-0.005^{* *}$ & $-0.004^{* *}$ \\
\hline & & $(0.001)$ & $(0.001)$ & $(0.002)$ & $(0.002)$ \\
\hline \multirow[t]{2}{*}{ InPOPULit -1 } & & & $-0.288^{* *}$ & $-0.322^{* *}$ & $-0.270^{*}$ \\
\hline & & & $(0.135)$ & $(0.147)$ & $(0.153)$ \\
\hline \multirow[t]{2}{*}{ UNEit } & & & & 0.008 & -0.006 \\
\hline & & & & $(0.018)$ & $(0.014)$ \\
\hline \multirow[t]{2}{*}{ LAWt } & & & & & -0.16 \\
\hline & & & & & $(0.104)$ \\
\hline \multirow[t]{2}{*}{ Constant } & $5.275^{* * *}$ & $5.149 * * *$ & $8.526^{* * *}$ & $8.568^{* * *}$ & $8.688^{* * *}$ \\
\hline & $(0.191)$ & $(0.197)$ & $(1.566)$ & $(1.621)$ & $(1.486)$ \\
\hline Observations & 60 & 60 & 60 & 60 & 60 \\
\hline R-squared & 0.011 & 0.256 & 0.427 & 0.435 & 0.452 \\
\hline Number of Canton & 10 & 10 & 10 & 10 & 10 \\
\hline \multicolumn{6}{|c|}{ Standard errors in parentheses } \\
\hline \multicolumn{6}{|c|}{${ }^{* *} p<0.01,{ }^{* *} p<0.05, * p<0.1$} \\
\hline
\end{tabular}

Source: Authors' estimates

Table 4 reports panel random-effects estimates of coefficients with robust standard errors. In order to specify the model in the details, we opted for stepby-step approach, starting with introduction of public debt as an accumulation of past deficits. Hence, the lagged deficit for one year initially represents the only explanatory variable (Est. 1). In the next step, we introduced the trade balance variable (Est. 2) with statistically significant negative coefficient suggesting that the increase in cantonal trade balance influences the reduction of the public debt in cantons. Furthermore, we added the variable size of population lagged for one year (Est. 3) and this variable has a negative impact on public debt suggesting that population growth in the previous year leads to higher share of public revenues in the current year, and consequently, higher public revenues reduce the need for borrowing. Est. 4 accounts for the impact of unemployment rate on cantonal public debt. Cantonal unemployment rate as a variable appears insignificant in all models. The reason behind this finding might be that in the model we use unemployment rate based on registered unemployment data by statistical offices, which use less strict definition in comparison to the International Labour Organization (ILO). As a matter of fact, large number of employees works in undeclared economy of $\mathrm{BiH}$, thus in $\mathrm{FBiH}$ as well (confirmed by
Pasovic and Efendic 2018; Efendic et al. 2018; Williams and Efendic 2020), which should be addressed in the future research. Finally, in our preferred model for interpretation, which is Est. 5, we introduce a dummy variable (LAW: 0 for period prior to 2015 and 1 for period afterwards) to control for institutional change introduced earlier.

The results in Table 4 demonstrate that $R^{2}$ values of the model grow by including additional explanatory variables and values are significantly higher in the last estimation (Est. 5) than that of the basic regression model (Est. 1), which is expected by authors. Independent variables in the model explain around $45 \%$ of variance in the dependent variable. All significant variables (budget deficit, trade balance and population) included in the model are of the expected sign.

The findings of the paper are in line with the current literature. We confirm that an increase in the total deficit has a positive effect on total public debt (e.g. in Benito and Bastida 2004; Bogumil et al. 2014; Omrane Belguith and Omrane 2017). More precisely, increase in budget deficit in the previous year by 10 million BAM leads to increasing of the public debt at cantonal levels for about $7 \%$ on average, while holding all other predictors in the model constant (this caveat will not be repeated later). Additionally, an increase in trade 
balance has the effect of reducing the public debt (see Santini 2020). Our model suggests that 10 million BAM of increase in the trade balance, ceteris paribus, reduces the public debt on subnational - cantonal level in $\mathrm{FBiH}$ for $0,4 \%$ on average. Furthermore, we find a significant and negative impact of the size of population on the public debt at subnational level in $\mathrm{FBiH}$. Impact of population on the public debt in $\mathrm{FBiH}$ can be explained by the LPRD in $\mathrm{FBiH}$ which prescribes the population as one of the criteria for the distribution of public revenues from indirect taxes. Accordingly, increase in population by $1 \%$ is associated with lower public debt per capita at subnational - cantonal level in $\mathrm{FBiH}$ by $0.27 \%$. Thus, bigger cantons enjoy this feature of having more population.

The existing literature also points to a positive relationship between unemployment and public debt indicating that an increase in the unemployment ends in higher public debt level (Veiga and Veiga 2014). Unemployment rate in our model is not significant, possibly because of the existence of relatively large shadow economy, already explained above. In accordance with the literature review and taking into account the fact that the amendment of the LPRD may have an impact on the overall fiscal capacity of the cantons, and thus on the public debt, we included an institutional variable of law changes in the model (Est. 5). This variable has a significant impact (if rounded on two decimal digits) on the canton's public debt.

\section{DISCUSSION}

Total public debt of cantons in $\mathrm{FBiH}$ in the period 2012-2018 increased from BAM 272 mil to BAM 420 mil, or from BAM 116 to BAM 191 per capita. Although still small as a nominal value per capita, the public debt in the period of seven years has increased for $65 \%$. If decision makers design fiscal policies that prove ineffective in tackling this public debt tendences, then further growing trajectory of the public debt might be expected. Inability to deliver local public goods, high quality public infrastructure or public capital formation are some of concerns of high and increasing public debt in cantons of $\mathrm{FBiH}$. Management of public debt at subnational levels is seriously challenged in times of economic crises such as the economic recession of 2008-09. Such challenges might be expected in the current economic downturn caused by Covid-19 virus pandemics. In Switzerland, for instance, most cantons imposed 'debt-brakes' in form of strict rules for subnational governments to adhere to in times of considerably high debt levels. No such mechanisms exist in FBiH. Fiscal rules laid in the Law on DBG are the only available tool in $\mathrm{FBiH}$ for public debt ceiling control while management of public debt is with subnational authorities.

In this paper a tribute is paid to fiscal institutions at state level when debt management is discussed (Musgrave and Musgrave 1989) meaning that even the strongest cantons, in terms of financial basis, cannot implement effective public debt management policy on their own. However, identifying influential determinants of public debt has utmost importance. First and foremost, public finance theory reminds us of public debt to be unavoidable consequence of large budget deficits. Whenever budget deficit at subnational government level surges it negatively affects total public debt, which our research confirms.

Cantons striving to alleviate public debt must design policies aiming at reducing budget deficits. In that context introduction of strong fiscal rules and other fiscal measures is highly recommended. At the same time government programs focused on alleviation of the unemployment can contribute to the fall in public debt. Although we lack sufficient economic growth data at cantonal level, recent economic growth in $\mathrm{FBiH}$ that was associated with public debt reduction clearly indicates that similar relationships can also be expected in cantons. This part of discussion should be explored in more details when more relevant data become available.

Other economic factors of influence on public debt, such as trade deficit that are examined in this paper, have been negatively associated with public debt. In this paper a trade-off between trade balance and public debt has been confirmed. If imports exceed exports then resulting indirect tax revenue increase (VAT, tariffs) alleviates fiscal deficit, but this is a short-run effect. However, other potentially negative effects of trade balance deficit in the long run, such as balance of payments changes and foreign exchange problems, must also be taken into account, but they are out of the scope of this paper. In future, reforms at cantonal levels oriented to creating businessfriendly environment should be much more visible. International rankings such as Doing Business Report, The Global Competitiveness Report, Global Index of Economic Openness, etc. show that there is space for accelerating of market-oriented reforms in $\mathrm{BiH}$.

The size of population as a variable in the model is identified to be important in the context of public debt at cantonal levels. An increase in the population size leads to smaller public debt per capita in cantons, which is not surprising outcome. However, this finding is very interesting in the light of external (out of $\mathrm{FBiH}$ and $\mathrm{BiH}$ ), but also internal migrations. $\mathrm{BiH}$ and South East Europe is traditionally an emigration region 
(Zbinden et al., 2016; Williams and Efendic, 2019), and this challenge should be carefully looked from the perspective of public finances in the future. We can identify both positive and negative internal migrations in cantons as well. Consequently, net internal annual migrations influence public debt per capita in the future period. Accordingly, cantons facing population decrease receive fewer public revenues, which is based on LPRD rule. This is a warning signal for cantons with negative internal migrations since they collect fewer financial resources for providing public goods which can further affect living standards in those cantons and cause even more migrations in the future.

Institutional changes in the form of changes in the formal rules (North 1990; Halebic 2011) that govern public finances, are also found to be important in debt management at subnational levels. Changes in laws that determine public revenues' shares between subnational units as well as intergovernmental levels can also affect public debt per capita in cantons and they need to be considered in the future considering rising debt tendences.

Finally, as the main limitation of our research we faced lack of available data at cantonal level to consider some potentially relevant influences on public debt identified in the similar literature. This could include examples as GDP growth rate, gross fixed capital formation as percentage of GDP, share of government to GDP, ratio of regional GDP to the national one, net savings, and similar. However, this research provides an important insight to the policy makers but also serves as a platform for further investigations when more data will be available.

\section{CONCLUSION}

This research examines determinants of public debt at subnational level, i.e. cantons in $\mathrm{FBiH}$ over the period 2012-2018. An empirical analysis was conducted with panel data to examine socio-economic and institutional factors that literature indicates as potentially important in exploring public debt at subnational government level. The obtained results have suggested that budget deficit, trade balance, and the size of population in these cantons have important influences on the public debt per capita. Those variables have obtained expected direction of influence and are thus consistent with similar studies. Other variables examined in the model (including here unemployment rate and institutional change) proved to be insignificant (institutional influence was on the border line of statistical significance at the 10\%). Sign of institutional variable was consistent while the unemployment rate proved to be inconsistent with relevant literature.

Analysis in this paper has shown that public debt at subnational levels can be caused by budget deficit, trade deficit, increase in size of population and specific institutional change. At the same time the paper also suggests that a weak link may exist between public debt and unemployment rate. Together these results provide important insights into the public debt analysis. However, more research should be done to examine other fiscal, economic and institutional factors that influence cantonal and municipal public debt in $\mathrm{FBiH}$ both in short and long term. 


\begin{tabular}{|c|c|c|c|c|c|c|}
\hline & Authors & Country & $\begin{array}{l}\text { Time } \\
\text { period }\end{array}$ & Article title & $\begin{array}{l}\text { Determinants of public debt } \\
\text { used in the research }\end{array}$ & Results \\
\hline 1 & $\begin{array}{l}\text { Ellis and } \\
\text { Schansberg } \\
\text { (1999) }\end{array}$ & SAD & $\begin{array}{l}1966- \\
1994\end{array}$ & $\begin{array}{l}\text { The } \\
\text { Determinants } \\
\text { of State } \\
\text { Government } \\
\text { Debt } \\
\text { Financing }\end{array}$ & $\begin{array}{l}\text { Dependent variables: the ratio of a state's } \\
\text { change in total debt to its expenditures for } \\
\text { a given year, ratio of a state's change in total } \\
\text { real debt to its population in a given year; } \\
\text { Explanatory variables: Demographic vari- } \\
\text { ables, Control variables: annual per capita } \\
\text { real income for each state, capital spending } \\
\text { to total spending and amount of real capital } \\
\text { spending per person; political variables } \\
\text { (political party affiliation of the governor, } \\
\text { the majority party of the state senate, and } \\
\text { the majority party of the state House); } \\
\text { Institutional variables (binary variable that } \\
\text { indicates whether the state senate and state } \\
\text { House are controlled by the same political } \\
\text { party, amount of intergovernmental transfers } \\
\text { from the federal government to each state } \\
\text { government, whether the governor has line } \\
\text { item veto power, }\end{array}$ & $\begin{array}{l}\text { The age group effects and income } \\
\text { growth exert important influences } \\
\text { on state debt financing decisions. } \\
\text { Political variables are largely ir- } \\
\text { relevant to debt financing. Strong } \\
\text { balanced budget requirements } \\
\text { and stringent debt limitations are } \\
\text { effective at limiting debt. }\end{array}$ \\
\hline 2 & $\begin{array}{l}\text { Benito and } \\
\text { Bastida } \\
\text { (2004) }\end{array}$ & Spain & $\begin{array}{l}1994- \\
1998\end{array}$ & $\begin{array}{l}\text { The determi- } \\
\text { nants of the } \\
\text { municipal } \\
\text { debt policy in } \\
\text { Spain }\end{array}$ & $\begin{array}{l}\text { Dependent variable: Variation (increase/de- } \\
\text { crease) of annual debt stock/ total revenues } \\
\text { (excluding indebtedness) } \\
\text { Explanatory variables: dummy coastal (non- } \\
\text { coastal and coastal municipalities), economic } \\
\text { level, population, political ideology, capital } \\
\text { expenditures, capital revenues, independ- } \\
\text { ence ratio (taxation revenues / total reve- } \\
\text { nues, excluding indebtedness), non-financial } \\
\text { surplus or deficit }\end{array}$ & $\begin{array}{l}\text { Financial variables that better } \\
\text { explain the issue of debt are non- } \\
\text { financial surplus/ deficit, financial } \\
\text { independence, capital expendi- } \\
\text { tures and capital revenues. Political } \\
\text { ideology does not affect local } \\
\text { indebtedness, population growth } \\
\text { has a positive effect on debt levels, } \\
\text { non-coastal municipalities have a } \\
\text { higher level of increase of borrow- } \\
\text { ing than the coastal ones. }\end{array}$ \\
\hline 3 & $\begin{array}{l}\text { Bogumil et } \\
\text { al. (2014) }\end{array}$ & Germany & 2010 & $\begin{array}{l}\text { Determinants } \\
\text { of local budg- } \\
\text { et deficits }\end{array}$ & $\begin{array}{l}\text { Dependent variable: municipal accumulated } \\
\text { debt and annual budget deficit } \\
\text { Explanatory variables: population, employ- } \\
\text { ment rate, purchasing power, workplace, } \\
\text { share in employment in the services sector, } \\
\text { population age quotient, Local council / City } \\
\text { Parliament, a city without a district, political } \\
\text { affiliation of the mayor. }\end{array}$ & $\begin{array}{l}\text { Debt is affected by exogenous } \\
\text { factors such as socio-economic } \\
\text { and demographic variables, } \\
\text { endogenous factors such as the } \\
\text { city, income sizes such as sales tax } \\
\text { revenues (for the debt level) as well } \\
\text { the amount of staff costs, the size } \\
\text { of parliament, reconciliation poli- } \\
\text { cies / conflict policies }\end{array}$ \\
\hline 4 & $\begin{array}{l}\text { Veiga and } \\
\text { Veiga } \\
(2014)\end{array}$ & Portugal & $\begin{array}{l}1979- \\
2011\end{array}$ & $\begin{array}{l}\text { Determinants } \\
\text { of Portuguese } \\
\text { local gov- } \\
\text { ernments' } \\
\text { indebtedness }\end{array}$ & $\begin{array}{l}\text { Dependent variable: real gross debt as a per- } \\
\text { centage of the three-year moving average } \\
\text { of total effective revenues (without loans) of } \\
\text { municipality "I" at year " } t \text { " (Debtit) (GMM) } \\
\text { Explanatory variables: investment expen- } \\
\text { ditures in total expenditures, interest on } \\
\text { debt payments in total expenditures, own } \\
\text { revenues in total revenues without loans, } \\
\text { unemployment, earnings, type of area, build- } \\
\text { ing permits or number of tourist facilities per } \\
\text { capita, election cycle or issues of the ruling } \\
\text { party }\end{array}$ & $\begin{array}{l}\text { Our results reveal that budget } \\
\text { deficits and debt increase in the } \\
\text { electoral year and, by a smaller } \\
\text { amount, in the previous. The struc- } \\
\text { ture of expenditures and revenues } \\
\text { also affects municipal budget bal- } \\
\text { ances and debt. Higher unemploy- } \\
\text { ment rates generate higher deficits } \\
\text { and debt. }\end{array}$ \\
\hline
\end{tabular}




\begin{tabular}{|c|c|c|c|c|c|c|}
\hline 5 & $\begin{array}{l}\text { Balaguer } \\
\text { Coll, } \\
\text { Prior and } \\
\text { Tortosa- } \\
\text { Austina } \\
\text { (2015) }\end{array}$ & Spain & 2008.g & $\begin{array}{l}\text { On the } \\
\text { Determinants } \\
\text { of Local } \\
\text { Government } \\
\text { Debt: Does } \\
\text { One Size Fit } \\
\text { All? }\end{array}$ & $\begin{array}{l}\text { Dependent variable: debt level per } \\
\text { inhabitant } \\
\text { Explanatory variables: capital expenditures, } \\
\text { net savings (funds available for investments), } \\
\text { non-financial deficit/non-financial surplus, } \\
\text { own fiscal capacity (revenues represented } \\
\text { by municipalities' own resources) expendi- } \\
\text { ture commitment (personnel and financial } \\
\text { expenditures)/(total expenditures); level of } \\
\text { tourism - index based on the (local) business } \\
\text { tax, level of economic activity, population } \\
\text { density; municipality's governing party; }\end{array}$ & $\begin{array}{l}\text { Debt is affected by: capital expen- } \\
\text { ditures, } \\
\text { non-financial surplus (as a share } \\
\text { of deficit), own fiscal capacity, and } \\
\text { tourism. }\end{array}$ \\
\hline 6 & $\begin{array}{l}\text { Bittencourt } \\
(2015)\end{array}$ & $\begin{array}{l}\text { South } \\
\text { America }\end{array}$ & $\begin{array}{l}1970- \\
2007\end{array}$ & $\begin{array}{l}\text { Determinants } \\
\text { of Gov't and } \\
\text { External Debt: } \\
\text { Evidence from } \\
\ldots\end{array}$ & $\begin{array}{l}\text { Dependent variable: government debt to } \\
\text { GDP } \\
\text { Explanatory variables: GDP growth rate, } \\
\text { trade openness, ratio of liquid liabilities to } \\
\text { GDP, inflation rate, share of urban popula- } \\
\text { tion, accounts for constraints on the execu- } \\
\text { tive, share of gov't to GDP, population, Gini } \\
\text { coefficients for income inequality. }\end{array}$ & $\begin{array}{l}\text { Local government debt is affected } \\
\text { by: growth and economic activity, } \\
\text { which also reduces public debt by } \\
\text { reducing government spending }\end{array}$ \\
\hline 7 & $\begin{array}{l}\text { Bellot, } \\
\text { Sellva and } \\
\text { Menendez } \\
\text { (2017) }\end{array}$ & $\begin{array}{l}\text { Europe } \\
\text { subna- } \\
\text { tional } \\
\text { level }\end{array}$ & $\begin{array}{l}1996 \\
-2010\end{array}$ & $\begin{array}{l}\text { Determinants } \\
\text { of sub-central } \\
\text { European } \\
\text { government } \\
\text { debt }\end{array}$ & $\begin{array}{l}\text { Dependent variable: direct debt variation in } \\
\text { region "i" for period "j" } \\
\text { Explanatory variables: GDP growth rate, } \\
\text { ratio of regional GDPpc to national average, } \\
\text { actual financing pc to regional average, total } \\
\text { regional debt-free financing in constant } € \\
\text { pc, operating income in constant } € \text { pc, share } \\
\text { of tax revenues in total revenues, share of } \\
\text { current expenditures in total expenditures, } \\
\text { population }+65, \text { population density, popula- } \\
\text { tion of lower level of gov't related to total } \\
\text { population, city as LGU, affiliation of regional } \\
\text { and central gov't to the same political op- } \\
\text { tion, variable which identifies the coopera- } \\
\text { tion of regional and central gov't and mutual } \\
\text { assistance, election year, }\end{array}$ & $\begin{array}{l}\text { Debt is affected by the amount of } \\
\text { public financing per capita (lower } \\
\text { financing per capita leads to higher } \\
\text { levels of debt). In addition, regions } \\
\text { characterized by higher debt-to- } \\
\text { GDP ratios tend to have lower } \\
\text { future deficits which is in line with } \\
\text { theories and previous research. } \\
\text { Almost all the political variables } \\
\text { have not had any influence in debt } \\
\text { variation. }\end{array}$ \\
\hline 8 & $\begin{array}{l}\text { Omrane } \\
\text { Belguith } \\
\text { and } \\
\text { Omrane } \\
2017\end{array}$ & Tunis & $\begin{array}{l}1986- \\
2015\end{array}$ & $\begin{array}{l}\text { Macro- } \\
\text { economic } \\
\text { determinants } \\
\text { of public } \\
\text { debt growth: } \\
\text { Tunisia }\end{array}$ & $\begin{array}{l}\text { Dependent variable: public debt as \% of GDP } \\
\text { Explanatory variables: GDP growth, gross } \\
\text { fixed capital formation as \% of GDP, inflation } \\
\text { (CPI), real interest rate, Openness/ Trade (ex- } \\
\text { ports + imports as a share of GDP), budget } \\
\text { deficit as \% of GDP. }\end{array}$ & $\begin{array}{l}\text { Inflation and investment reduce } \\
\text { the level of public debt. The real } \\
\text { interest rate, budget deficit and } \\
\text { trade openness increase the public } \\
\text { debt. Budget deficit is the most } \\
\text { important determinant of public } \\
\text { debt. }\end{array}$ \\
\hline
\end{tabular}




\section{Endnotes:}

1 Una-Sana Canton, Posavina Canton, Tuzla Canton, Zenica-Doboj Canton, Bosnian-Podrinje Canton Gorazde, Central Bosnia Canton, Herzegovina-Neretva Canton, West Herzegovina Canton, Sarajevo Canton, Canton 10.

2 Such as: tax on property, property transactions, inheritance, transgressions, and some parafiscal taxation in the field of communal, administrative and legal affairs.

3 Primary fiscal deficit is allowed only in times of natural disasters and government is obliged to counterbalance it during next five fiscal years.

4 Following equation: $\Delta \mathrm{D}=$ (primary deficit/GDP) + (real interest rate - growth rate) $\times \Delta \mathrm{D}$; where: $\Delta \mathrm{D}$ stands for the ratio of government debt to GDP, is standard formulae for debt dynamics discussion (Fisher and Easterly 1990). The basic logic of the equation is that change in the debt ratio $(D)$ is equal to the primary deficit of public sector plus the debt ratio multiplied by the difference between average real interest rate on the debt and the growth rate of GDP. Obviously, the debt dynamics is influenced by this difference between the real interest rate and the economic growth rate. In case of positive primary deficit and the real interest rate being higher than the economic growth rate, the resulting debt to GDP ratio will continuously rise. This situation can hardly be sustainable since at some point in time the government will not be able to sell more debt for the purpose of financing the budget deficits. Another way of offsetting its initial debt for governments is to run primary surpluses (Romer 2019). Currently, measuring of GDP on subnational level in $\mathrm{FBiH}$ is not available, so discussion of government budget constraint for purposes of debt dynamics assessment is not possible.

As for the transversality condition which deals with sustainability of the debt in the context of this paper the subnational public debt in $\mathrm{FBiH}$ will be prevented from growing on an exponential rate (the snowball effect) only if the transversality condition is met. And this condition is met when the growth of private and of the public debt is lower than the real interest rate charged on this debt in the infinite horizon (Azizi et al. 2013). Again, here we were faced with data availability issue since real interest rate is not measured on subnational levels in $\mathrm{FBiH}$.
Tax-smoothing model at its basic idea considers distortions in individual choices with resulting inefficiencies caused by taxes and recommends moderate tax rates over continuous changes of high and low tax rates periods. Since most important tax competences in $\mathrm{FBiH}$ regarding value added tax, corporate income tax and personal income tax are set on higher than subnational levels we considered tax-smoothing hypothesis not relevant for study in this paper. Fiscal system in $\mathrm{FBiH}$ is structured in a way to use the distribution of public revenues (more precisely, some cantons in $\mathrm{FBiH}$ have higher public revenues' distributional coefficients than others such as: Posavina Canton, Bosnian-Podrinje Canton) for smoothing insufficient taxes that are needed to finance government spending in those subnational government levels that are considered fiscally unsustainable.

5 According to the 2010 Law on Debt, Borrowing and Guarantees in FBIH (DBG), cantonal governments can contract long-term debt only if their total debt repayment in a given year does not exceed $10 \%$ of the previous year's revenues.

6 www.cpi.ba (access: 28.01.2020.)

7 Except for 2018, which was taken from a report by the Federal Ministry of Finance.

8 The law amendments from 2015 did not change the main model of public revenues between $\mathrm{FBiH}$ and cantons but intergovernmental relations were modified in the way that the share of $\mathrm{FBiH}$ in indirect tax revenues' distribution increased while the share of cantons decreased. Financing of Canton Sarajevo dropped additionally upon inclusion of City of Sarajevo in this mode of revenue distribution.

9 In accordance with the Law on DBG in the $\mathrm{FBiH}$, the budget deficit is used as a determinant of public debt, while the non-financial deficit/surplus is used in the literature review which we do not consider a problem since deficit definition might be country specific.

10 Variables with large monetary values as well as population were generally recommended to be inserted in models with logarithmic transformations (Wooldridge 2016). For variables that have had a large monetary value but some of them with negative sign such as DEF and TRDB, we did not used their logarithmic transformations. 


\section{REFERENCES}

Albu, L.L. and Pelinescu, E. 2000. Sustainability of the public debt and deficit. RCEP Working paper 4.

Alesina, A. and Passalacqua, A. 2016. The political economy of government debt. In Handbook of Macroeconomics, edited by J.B. Taylor and H. Uhlig, 2599-651. Amsterdam/ Oxford: Elsevier.

Ashworth, J., Geys, B. and Heyndels, B. 2005. Government weakness and local public debt development in flemish municipalities. International Tax and Public Finance 12 (4): 395-422. doi:10.1007/s10797-005-2317-3.

Azizi, K., Canry, N., Bernard Chatelain, J. and Tinel, B. 2013. Government solvency, austerity and fiscal consolidation in the OECD: a Keynesian appraisal of transversality and no ponzi game conditions. Documents de Travail du Centre d'Economie de la Sorbonne 42.

Balaguer-Coll, M.T., Prior, D. and Tortosa-Ausina, E. 2015. On the determinants of local government debt: does one size fit all? International Public Management Journal. do i:10.1080/10967494.2015.1104403.

Basaric, H., Brankovic, N. and Lazovic-Pita, L. 2018. Bosnia and Herzegovina: local government debt. In Fiscal decentralisation, local government and policy reversals in Southeastern Europe, edited by W. Bartlett, S. Kmezic and K. Djulic. Cham: Palgrave Macmillan.

Bellot, N.J., Selva, M.L.M. and Menéndez, L.G. 2017. Determinants of sub-central European government debt. The Spanish Review of Financial Economics 15 (2): 52-62. doi:10.1016/j.srfe.2017.04.001.

Benito, B. and Bastida, F. 2004. The determinants of the municipal debt policy in Spain. Journal of Public Budgeting, Accounting \& Financial Management 16 (4): 492-525. doi:10.1108/JPBAFM-16-04-2004-B002.

Bisogno, M., B. Cuadrado-Ballesteros, S. Santis, and F. Citro. 2019. Budgetary solvency of Italian local governments: an assessment. International Journal of Public Sector Management 32 (2): 122-141. doi:10.1108/ IJPSM-11-2017-0328.

Bittencourt, M. 2015. Determinants of government and external debt evidence from the young democracies of South America. Emerging Markets Finance and Trade 51 (3): 463-472. doi:10.1080/1540496X.2015.1025667.

Bogumil, J., Holtkamp, L., Junkernheinrich, M. and Wagschal, U. 2014. Ursachen kommunaler Haushaltsdefizite [Determinants of local budget deficits]. Politische Vierteljahresschrift [Political Quarterly] PVS 55 (4): 614647. doi:10.5771 /0032-3470-2014-4-614.

Bökemeier, B. and Clemens, C. 2016. Does it pay to fulfill the Maastricht convergence criteria? - reflections on the public debt and growth nexus for selected European economies. CESIFO Working paper 6161.

Bröthaler, J., Getzner, M. and Haber, G. 2015. Sustainability of local government debt: a case study of Austrian municipalities. Empirica 42: 521-546. doi:10.1007/ s10663-014-9261-3.

Ehalaiye, D., Botica-Redmayne, N. and Laswad, F. 2017. Financial determinants of local government debt in New Zealand. Pacific Accounting Review 29 (4): 512-533. doi:10.1108/PAR-11-2016-0104.

Efendic, N., Pasovic, E. and Efendic, A. 2018. Understanding informal economy in practice - evidence from Bosnia and Herzegovina. The Financial Internet Quarterly "eFinanse" 14 (4): 77-89.

Ellis, M. A. and Schansberg, D. E. 1999. The determinants of state government debt financing. Public Finance Review 27 (6): 571-587. doi:10.1177/109114219902700601.

Feld, L.P. and Kirchgässner, G. 2001. Does direct democracy reduce public debt? Evidence from Swiss municipalities. Public Choice 109 (3-4): 347-370. doi:10.1023/a:1013077121942.

Fisher, S. and Easterly, W. 1990. The economics of the government budget constraint. The World Bank Research Observer 5 (2): 127-142.

Franks, J., Barkbu, B., Blavy, R., Oman, W. and Schoelermann, $\mathrm{H}$. 2018. Economic convergence in the Euro area: coming together or drifting apart? IMF European Department Working Paper 18/10.

Gorina, E. 2013. Fiscal sustainability of local governments: effects of government structure, revenue diversity, and local economic base. PhD Dissertation, Phoenix: Arizona State University.

Halebic, J. 2011. Role and significance of economic institutions in economic development of Bosnia and Herzegovina. Zenica: University of Zenica.

Kächelein, H., Lami, E. and Imami, D. 2010. Elections related cycles in publicly supplied goods in Albania. BERG Working Paper Series on Government and Growth. https://www.econstor.eu/handle/10419/38822.

Kirchgässner, G. 2013. Fiscal institutions at the cantonal level in Switzerland. Swiss Journal of Economics and Statistics 149 (2): 139-166. doi:10.1007/BF03399386.

Kitchen, H., McMillan, M. and Shah, A. 2019. Local public finance and economics - an international perspective. Cham: Palgrave Macmillan.

Koomin, K. and Seunghoo, L. 2018. Determinants of state long-term debt: The political market framework. The Social Science Journal 55: 359-368.

Kose, M.A., Nagle, P., Ohnsorge, F. and Sugawara, N. 2020. Global waves of debt: causes and consequences. Washington DC: International Bank for Reconstruction and Development / The World Bank.

Krugman, P., and R. Wells. 2018. Macroeconomics. 5ed New York: Worth Publishers Macmillan Learning.

Lami, E., Kachelein, H. and Imami, D. 2014. A new view into political business cycles: household expenditures in Albania. Acta Oeconomica 64: 201-224. 
Mahdavi, S. 2014. Bohn's test of fiscal sustainability of the American state governments. Southern Economic Journal 80 (4): 1028-1054. doi:10.4284/0038-4038-2012.223.

Medve-Bálint, G. and Bohle, D. 2016. Local government debt and EU funds in the Eastern member states: the cases of Hungary and Poland. MAXCAP Working Paper No. 33: 3-28.

Musgrave, R.A. and Musgrave, P.B. 1989. Public finance in theory and practice. 5ed New York: McGraw Hill Higher Education.

North, D.C. 1990. Institutions, institutional change and economic performance. Cambridge: Cambridge University Press.

Omrane Belguith, S. and Omrane, H. 2017. Macroeconomic determinants of public debt growth: a case study for Tunisia. Theoretical and Applied Economics XXIV (4): 161-168.

Pasovic, E. and Efendic, A. 2018. Informal economy in Bosnia and Herzegovina - an empirical investigation. South East European Journal of Economics and Business 13 (2): 112-125.

Pettersson-Lidbom, P. 2001. An empirical investigation of the strategic use of debt. Journal of Political Economy 109 (3): 570-583.

Romer, D. 2019. Advanced macroeconomics. New York: McGraw-Hill Education.

Santini, G. 2020. Economic approach to taxation - VAT, tax of future. Zagreb: Rifin.

Sinha, P., Arora, V. and Bansal, V. 2011. Determinants of public debt for middle income and high income group countries using panel data regression. MPRA Paper 32079.

Skidelsky, R. 2018. Money and government: the past and future of economics. New Haven and London: Yale University Press.

Stiglitz, J.E. and Rosengard, J.K. 2015. Economics of the public sector $4^{\text {ed }}$ New York / London: W. W. Norton \& Company, Inc.

Tokarski, P. 2019. Divergence and diversity in the Euro area: the case of Germany, France and Italy. SWP Research Paper Berlin.

Veiga, L. G. and Veiga, F. J. 2014. Determinants of Portuguese local governments' indebtedness. NIPE Working Paper 16: 10-20.

Wassmer, R. W., and R. C. Fisher. 2011. State and local government debt, 1992-2008. State Tax Notes 341.

Williams, C. C. and Efendic, A. 2020. Evaluating the relationship between migration and participation in undeclared work: lessons from Bosnia and Herzegovina. Economic Alternatives 2: 592-606. doi: https://doi.org/10.37075/ EA.2020.4.06

Williams, N. and Efendic, A. 2019. Internal displacement and external migration in a post-conflict economy: Perceptions of institutions among migrant entrepreneurs. Journal of International Entrepreneurship 17: 558-585.

Wooldridge, J.M. 2016. Introductory Econometrics: a Modern Approach. Boston, USA: Cengage Learning.

Zbinden, M., Dahinden, J. and Efendic, A. 2016. Diversity of migration in South-East Europe. Bern: Peter Lang. 